\title{
505 ハプティックインターフェースを用いたはんだ付け教示システム Hand Soldering Teaching System Using Haptic Interfaces
}

\author{
○学 遠藤 文也（東洋大）正山川 聡子（東洋大）
}

Fumiya ENDO and Satoko YAMAKAWA, Toyo University, Kujirai2100, Kawagoe, Saitama

\begin{abstract}
Training systems with haptic interfaces are very effective because they can give operators the reaction force like in the real operations. In this study, a soldering teaching system with two haptic interfaces is constructed for learning the correct procedure and timing of soldering. The operator can manipulate a virtual soldering iron and a solder constructed in the virtual space via the pen-type haptic interfaces. The haptic interfaces give an operator not only the reaction force but also the guidance force for achieving the correct procedure and timing of soldering. The training effect by using the constructed system and the effect of the guidance force were evaluated in the experiments.
\end{abstract}

Key Words: Haptic interface, Virtual reality, Teaching system, Soldering

\section{1. 緒言}

バーチャルリアリティを表現する方法の一つとして，人 間の触覚を刺激して対象物に触れた時に反力を提示する八 プティックインターフェースが注目されている. 力提示を 用いることで実環境に近い感覚を体験でき, 力感覚を重要 とする訓練システムでは大変有効[1]と言える.

従来の研究[2]では, 熟練者から訓練者への書道の技能伝 達を目的とした研究などが存在する.これらの研究では熟 練者の動きをあらかじめ記録し，ハプティックインターフ ェースを介して訓練者に力提示をして，訓練者の主体性を 活かした教示について検討している。

本研究では，正しい手順のはんだ付け[3]を教示するシス テムを構築する．2台のハプティックインターフェースを 用いて操作者に適切な動きを誘導する力提示をする．訓練 者は両手でペン型の形状をしたハプティックインターフェ 一スを操作することで仮想空間内に構築したはんだごて, はんだのモデルを操作する. VR 技術を用いたシステムで の教示の効果と力提示の効果を検証する.

\section{2. 実験装置}

実験装置として Fig.1 に示す SensAble Technologies 社の ハプティックインターフェース PHANToM Omni(以後 PHANToM)を用いる. PHANToM は手先の位置や姿勢の検 出, カフィードバックを行うことが出来る. 位置姿勢の自 由度は 6 である. Fig.2 は PHANToM を横から見たモデルで あり, $\theta_{1}, \theta_{2}, \theta_{3}$ は各ジョイント角度, $\theta_{4}, \theta_{5}, \theta_{6}$ はペンのジンバ ル角である. また, $L_{1}, L_{2}, L_{3}$ は各関節の長さである. 開発ツ 一ルキットである Open Haptics Toolkitを用いることで，仮 想空間に物体を構築, 描画し, PHANToM の力制御をする ことが出来る.

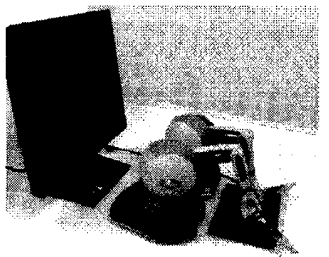

Fig.1 PHANToM Omni

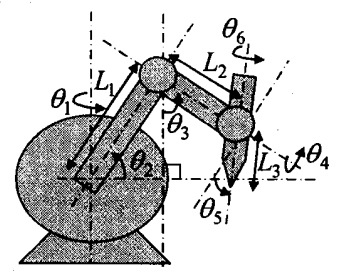

Fig. 2 Joint angles

\section{3. システムの構成}

Fig.3のように 2 台の PHANToM を設置する．作業空間 の座標系は, 鉛直上向きを $y$ 軸, 手前を $z$ 軸として $L_{1}$ の根 本の回転中心から正面 $180[\mathrm{~mm}]$ に原点をおく．また， $x$ 軸 負方向 $160[\mathrm{~mm}]$ の位置に 2 台目の PHANToM を設置する.

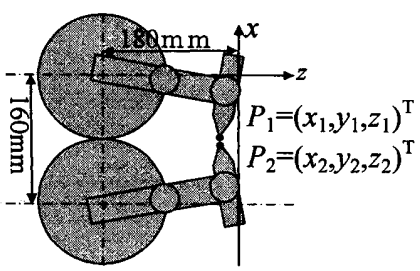

Fig.3 The coordinate system of workspace

Fig.1のようにモニタは, 実際の作業環境に近付けるため, PHANToM の前方, $x z$ 平面に平行に $y$ 軸負方向 $110[\mathrm{~mm}]$ の 位置に設置した。 また, PHANToM の後方，垂直にモ二タ を設置し, 実験を行いモニタの設置場所の影響も比較する.

仮想空間の $x z$ 平面に基板を構築し，モニタと仮想空間の $x z$ 平面が平行になるように表示する。これは基板を真上か ら見ていることに相当する。モニタを垂直に設置する場合 は，仮想空間を作業環境に対して $90^{\circ}$ 回転させ，モニタと 仮想空間の $x y$ 平面が平行になるように表示する.

\section{1 手先の位置}

作業空間の座標系における右手ペン先の位置 $P_{1}=\left(x_{1}, y_{1}, z_{1}\right)^{\mathrm{T}}$ は以下で表される。

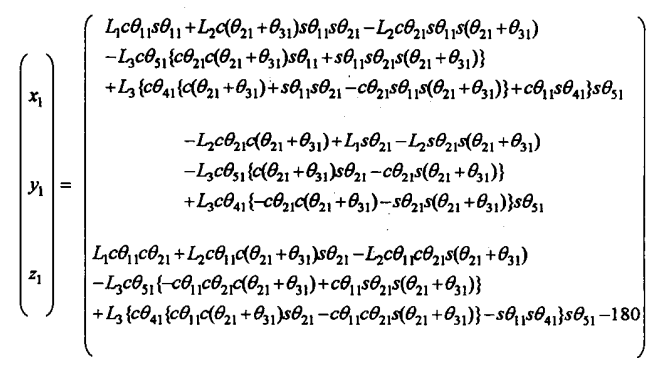

また, 左手ペン先の位置 $P_{2}=\left(x_{2}, y_{2}, z_{2}\right)^{\mathrm{T}}$ は以下で表される.

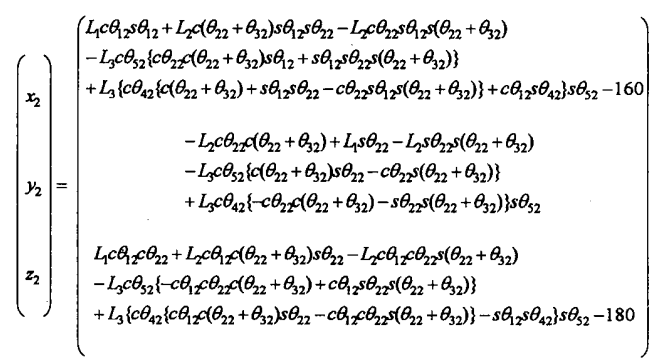

ただし, $\mathrm{s} \theta$ は $\sin \theta, \mathrm{c} \theta$ は $\cos \theta$ を表し， $\theta_{\mathrm{j} 1}, \theta_{\mathrm{j} 2}$ はそれぞれ右 手側，左手側の PHANToM $の \mathrm{j}$ 番目の関節角を表す.

実環境でのペン先の動きに合わせて，仮想空間内のはん だごて，はんだの先端の位置および角度を動かす。また， 作業環境の $1[\mathrm{~mm}]$ が仮想空間の $1[\mathrm{~mm}]$ となるようにした. 
3.2 はんだ付けのモデル化

はんだ付け作業で生じるイベントが発生する時刻を以下 のように定義する.

$t_{A}:$ はんだごてを暖め始めた時刻

$t_{B}:$ はんだごてが接合部に接触した時刻

$t_{C}$ : はんだが接合部に接触した時刻

$t_{D}:$ はんだを接合部から離した時刻

$t_{E}:$ はんだごてを接合部から離した時刻

$t_{F}:$ スポンジではんだごてを拭いた時刻

これらのイベントに着目してモデル化を行う. Fig.4のよ うに仮想空間内に構築した基板やスポンジに触れたときに 操作者に提示する $y$ 方向の反力は以下の式で表す.

$$
f=\left\{\begin{array}{l}
k \xi, \xi<0 \\
0, \xi \geq 0
\end{array}\right.
$$

ここで, $k$ は弾性係数 $[\mathrm{N} / \mathrm{mm}], \xi$ は仮想物体への押し込み 量を示す。また，仮想のはんだごては，システムの起動か ら時間とともに，ある限界值 $T_{\max }$ になるまで温度が上昇す る。また，スポンジではんだごてを拭くと温度が低下し， スポンジから離すと再び $T_{\max }$ まで上昇する. 温度が上がり 始める時刻 $t_{A}$ ，下がり始める温度 $t_{F}$ を用いて，時刻 $t$ にお けるはんだごての温度 $T_{I}(t)$ を以下の式で表す。

$$
\begin{array}{ll}
T_{1}(t)=\min \left(T_{1}\left(t_{A}\right)+\alpha\left(t-t_{A}\right), T_{\max }\right) & ,\left(t_{A} \leq t<t_{F}\right) \\
T_{1}(t)=\max \left(T_{1}\left(t_{F}\right)-\alpha\left(t-t_{F}\right), 0\right) \quad,\left(t_{F} \leq t<t_{A}\right)
\end{array}
$$

ただし， $a$ を定数とする．また，はんだの融点温度を $T_{0}$ と すると，はんだが溶ける条件は以下で表される。

$$
T_{1}(t) \geq T_{0}
$$

次に,はんだごてとはんだの接触判定を以下の式で示す.

$$
\varepsilon \geq \sqrt{\left(x_{1}-x_{2}\right)^{2}+\left(y_{1}-y_{2}\right)^{2}+\left(z_{1}-z_{2}\right)^{2}}
$$

ただし， $\varepsilon$ は十分に小さな定数とする. 式(6)，(7)の条件を 満たした場合，熱を持ったはんだごてがはんだを溶かす。 この時の溶けたはんだは半球と仮定し, 溶け始めの時刻以 降, 体積が一定の割合で増えるようにモデル化した。

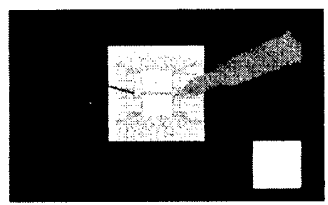

Fig.4 Virtual objects

\section{4. 教示方法}

\section{1 視覚教示}

操作者に，はんだ付けの正しいタイミングを視覚的に教 示する．あらかじめ熟練者の動きを記録し，熟練者のはん だごて，はんだが基板に触れている間のみ「touch」と仮想 空間上に表示する．操作者はそれぞれのカーソルに対応し た表示に合わせて基板に触れ，表示が消えたら離すという 動作を繰り返し行うことで正しいはんだ付けを学ぶ。

\section{2 力覚教示}

はんだ付けを行う目標位置を $P=(x, y, z)^{\mathrm{T}}$ とする．目標位 置への力提示は以下のバネ力 $f_{t}$ で表す.

$$
\boldsymbol{f}_{t}=k_{t}\left(\boldsymbol{P}_{n}-\boldsymbol{P}\right) \quad,(n=1,2)
$$

ここで, $k_{t}$ は弾性係数であり， $k_{t}>0$ であれば $\boldsymbol{P}$ に引き寄せ られ， $k_{t}<0$ であれば $\boldsymbol{P}$ から引き離される力提示である。

「touch」が表示された瞬間に $k_{t}>0$ ，表示が消えた瞬間に $k_{t}<0$ とする. ただし，操作者にある程度の主体性を持たす
ため, 力提示する範囲に閶値 $L_{t h}(>0)$ を設ける.

$$
\left|\boldsymbol{P}_{n}-\boldsymbol{P}\right| \leq L_{t h} \quad,(n=1,2)
$$

\section{5. 実験方法}

\section{1 実験内容}

構築したシステムの有効性を検証するため実験を行った. 被験者は 20 代男女 6 名である. 被験者を 2 グループに分 け, 被験者 $\mathrm{A}, \mathrm{B}, \mathrm{C}$ はモ二夕を水平, 被験者 $\mathrm{D}, \mathrm{E}, \mathrm{F}$ は垂直に 設置して実験を行った。教示前, 視覚教示後, 力覚教示後 に実際のはんだ付けを行った。ただし，教示時間は 3 分間 （仮想空間内でのはんだ付け 20 回程度）とし，視覚教示と 力覚教示の実験は 1 日以上の間隔を空け行った。ここでの 提示力の弹性係数は $k=1.0, k_{t}=0.4$ とした. はんだ付けの様 子を高速力メラで撮影し, 教示前, 教示後で各イベントが 発生した時刻を計測した。

\section{2 実験結果}

Fig. 5 に被験者 6 名の実験結果を示す. 教示前, 多くの被 験者において, はんだごてとはんだが接触させる手順が熟 練者とは異なったり， $t_{C}, t_{D}$ 間のタイミングが早かったりし た。そのため，教示前は接合部に十分な量のはんだを供給 出来ていないはんだ過小, 突起などのはんだ付け不良が見 られた。教示前の熟練者と全被験者の $t_{B}$ の差の 2 乗和は 1.02 であり，これははんだごてよりはんだを先に接合部に あてたことを表す. 視覚教示後は 0.26 , 力覚教示後は 0 と なり全被験者が熟練者の手順と等しくなった。また，はん だ付けを終了する時刻 $t_{E}$ における熟練者と全被験者の差の 2 乗和は教示前 6.36 , 視覚教示後は 5.51 , 力覚教示後は 2.54 であり力覚教示を行うことで作業のタイミングが熟練者の 手順に近づいたと言える。 また，実際にはんだ付けの形状 を比較すると，はんだ付け不良が減っていた．訓練によっ て，熟練者と同様の正しい手順とはんだを溶かすために適 切なタイミングを学んだためはんだ付け不良が減少したと

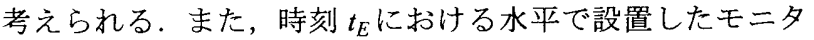
で教示を行ったグループの差の 2 乗和は 1.15 で, 垂直に設 置したグループの差の 2 乗和の 2.27 の半分程度になった。

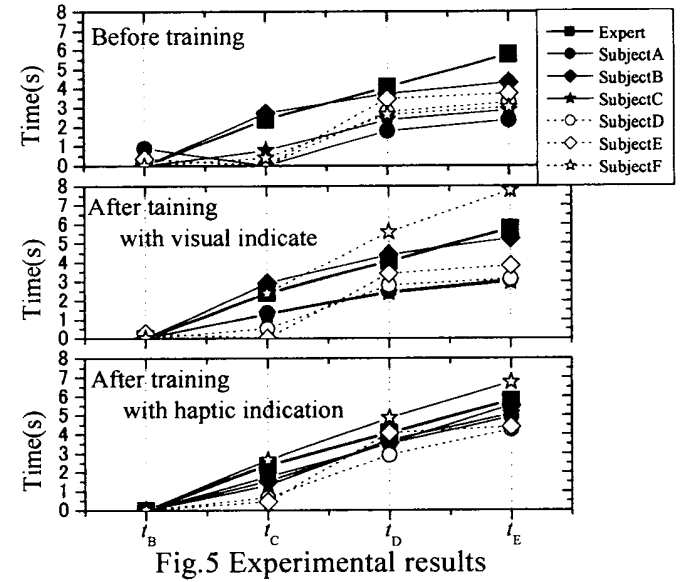

\section{6. 結言}

本研究では，VR 技術を用いて，はんだ付けの正しい手 順やタイミングを教示するシステムを構築した。実験を行 い, 視覚情報, 力覚情報が訓練に与える影響を調べた. そ の結果, 力提示を行うことで作業のタイミングが教示デー タに近づく傾向が確認された.

\section{参考文献}

[1] 舘, 佐藤, 廣瀬 : バーチャルリアリティ学日本バーチャルリア リティ学会編, コロナ社, 2011

[2] 瑳俄, 川上, 舘: 日本バーチャルリアリティ学会論文誌,

Vol.10, No3, 2005, pp.363-369.

[3] 野瀬：目で見てわかるはんだ付け作業，日刊工業株式会社， 2009 